\title{
Time course effect of lipopolysaccharide on Toll-like receptors expression and steroidogenesis in the Chinese goose ovary
}

\author{
Shijia Ying ${ }^{1}$, Jiajia Guo ${ }^{1,2}$, ZiChun Dai ${ }^{1}$, HuanXi Zhu ${ }^{1}$, JianNing Yu ${ }^{1}$, WeiMing Ma², JiaYi Li $^{3}$, \\ Muhammad Faheem Akhtar ${ }^{1}$ and ZhenDan Shi ${ }^{1}$ \\ ${ }^{1}$ Institute of Animal Science, Laboratory of Animal Improvement and Reproduction, Jiangsu Academy of Agricultural \\ Sciences, Nanjing, China, ${ }^{2}$ College of Animal Science and Veterinary Medicine, Shandong Agricultural University, \\ Taian, Shandong, China, and ${ }^{3}$ College of Animal Science and Technology, Nanjing Agricultural University, Nanjing, \\ Jiangsu, China
}

Correspondence should be addressed to ZhenDan Shi; Email: zdshi@jaas.ac.cn

\begin{abstract}
The ovary of Chinese goose is easily infected by microorganisms because of the mating behaviour in water, which causes decreased laying performance. This study investigated the time course effect of lipopolysaccharide (LPS) on the steroidogenesis and mRNA expression of Toll-like receptors (TLRs), a class of key pattern recognition receptor, in the breeding goose ovary. The laying geese were treated intravenously with LPS for $0,6,12,24$ and $36 \mathrm{~h}$, and all birds were slaughtered approximately $8 \mathrm{~h}$ after oviposition. The expression levels of TLRs in the white and yellowish follicles, and granulosa and theca layers of hierarchical follicles were examined by real-time PCR. All 10 members of avian TLR family were differentially expressed among the different follicular tissues. Moreover, at 24 and $36 \mathrm{~h}$ after LPS treatment, the hierarchical follicle morphological structure was altered, but the expression levels of $T L R \mathrm{~s}$ were still higher than the control. Furthermore, during LPS treatment period, the expression pattern of TLRs $2 A$ and 4 genes was similar to that of TLR15 in the white follicles, TLRs $1 B, 5$ and 15 in the yellowish follicles, TLRs 7 and 15 in the granulosa layer, and TLRs $1 A, 2 B, 3,7$ and 15 in the theca layer, which had a negative correlation with the kinetics of plasma P4 and E2 concentrations. In conclusion, the mechanism by which pathogen infection inhibited goose follicular growth and further decreased egg production may involve a gradually enhanced inflammatory response and reduced endocrine function. This may be due to stimulated TLRs in the ovary.

Reproduction (2017) 153 509-518
\end{abstract}

\section{Introduction}

Similar to the domestic chicken ovary, the goose ovary contains numerous prehierarchical and preovulatory follicles that ovulate on successive days (Qin et al. 2013); however the female goose could lay only 50-60 eggs throughout the course of the breeding season. In addition, the ovary is susceptible for pathogenic bacterial infection due to the particular mating behaviour on the water containing pathogens from faecal excretions, which may reduce the laying performance in goose (Jiang et al. 2011, Yang et al. 2012). The ovarian steroid hormones regulate follicular development, atresia and ovulation in avian species (Johnson 2012, 2015). The deleterious effect of pathogens on follicular growth may involve the direct action on follicles, since TLRs recognising the pathogens are present in follicles (Subedi et al. 2007, Michailidis et al. 2010, Brownlie \& Allan 2011). However there is little information about dynamic changes of steroid hormones and TLRs expression levels in responses to bacterial infection in the goose ovarian follicles.
TLRs have been identified as the key components of innate immune response in animal, providing the first line of defence against potential pathogens (Aderem \& Ulevitch 2000, Akira et al. 2001, Subedi et al. 2007, Michailidis et al. 2010, 2014, Brownlie \& Allan 2011). To date, 10 types of TLRs, including TLRs $1 A, 1 B$, $2 A, 2 B, 3,4,5,7,15$ and 21 , have been identified in chicken (Subedi et al. 2007, Temperley et al. 2008, Michailidis et al. 2010). It has been reported that some TLRs were expressed in the chicken ovary, and were stimulated by LPS or Salmonella enteritidis (SE), indicating a TLR-mediated immune response mechanism (Subedi et al. 2007, Michailidis et al. 2010). Moreover, TLRs have been hypothesised to take part in follicular development and ovulation (Woods et al. 2009, Kannaki et al. 2011). In vitro experiments suggest that LPS or SE treatment lead to the differential regulation of TLRs based on the stage of follicular maturation, with the largest follicle granulosa cells having the most rapid immune response and the undifferentiated granulosa cells being more sensitive to LPS/SE-induced apoptosis (Woods et al. 2009, Wang et al. 2014). Additionally, 
the granulosa cell proliferation and steroidogenesis are inhibited during the SE infection (Tsai et al. 2010, Wang et al. 2014).

The LPS, derived from gram-negative bacteria, is usually used to mimic bacterial infections. It is now well established that LPS not only induces the host immune response, but also has a detrimental effect on cell function (Cronin et al. 2012, Saut et al. 2014, Oguejiofor et al. 2015). The LPS-mediated ovarian inflammatory response, reduced steroidogenesis, increased cell apoptosis, and inhibited follicular and luteal growth in mammals have been elaborated in previous studies (Herath et al. 2007, Herzog et al. 2012, Bromfield \& Sheldon 2013, Luttgenau et al. 2016b). Furthermore, these procedures are mediated via TLRs 2 and 4 pathways (Shimada et al. 2008, Bromfield \& Sheldon 2011, Price \& Sheldon 2013, Price et al. 2013, Glynn et al. 2014, Luttgenau et al. 2016a). Recently the synergistic effect of TLRs 4 and 5 to initiate the innate immune responses against Escherichia coli (E. coli) infection has been described in mouse epididymal epithelial cells (Cheng et al. 2016), which indicates a potential interaction among TLRs. Moreover, the other TLRs, including TLRs $1 A, 7,15$ and 21 , could be induced by LPS in chicken Sertoli cells (Michailidis et al. 2014). It is proposed that in addition to TLRs 2 and 4, LPS could induce the expression of the other TLRs in the ovarian follicles, which perturbs ovarian function.

Therefore this study was initially designed to determine the expression pattern of TLR families, and then to investigate time course effect of LPS treatment on the expression levels of TLR families and steroidogenesis in the goose ovarian follicles.

\section{Materials and methods}

\section{Experimental birds}

The experiment was conducted at the Yangzhou Goosing Agricultural Science and Technology Co., Ltd (Jiangsu, China; longitude $119.39^{\circ}$ and latitude $\left.32.59^{\circ}\right)$. The geese of age 540 days approximately at peak laying were placed in pens containing artificial water pool, slate floor bed and living area. The living area was under low light intensity at night. The others were kept under natural photoperiod. The birds were provided with feed and water ad libitum. All experimental procedures were approved by the Institutional Animal Care and Use Committee of Jiangsu Academy of Agricultural Sciences, and performed according to the guide for animal care and use of laboratory animals.

\section{Experimental design}

A stock solution of LPS was prepared by dissolving LPS from E. coli 055:B5 (Sigma) in Dulbecco's phosphate buffer (D-PBS; Gibco). The changes in the expression levels of TLRs in follicles were examined at $0,6,12,24$ and $36 \mathrm{~h}$ after the injection of LPS (1.5 mg/kg BW). Ten geese were selected immediately after LPS injection for $0 \mathrm{~h}$ as the control, while five geese were selected at other time point. All experimental birds were slaughtered $8 \mathrm{~h}$ after oviposition by cervical dislocation, and the blood samples were collected. In all experiments, the white and yellowish follicles, and granulosa and theca layers of hierarchical follicles were collected. The follicular tissues from the control group were used to analyse the changes in the $T L R s$ mRNA expression during follicular growth. The spleen from the control group was used to determine the expression of $T L R$ s as a positive control.

\section{Blood collection}

The blood sample $(2 \mathrm{~mL})$ from each bird was collected through the wing venipuncture, and immediately placed in ice-cold heparinised tubes just before slaughtering. The serum was separated by centrifugation at $4{ }^{\circ} \mathrm{C}$, diluted three times and stored at $-20^{\circ} \mathrm{C}$ for hormonal measurements.

\section{Laying behaviour determination}

The methods for determining the laying behaviour were used with modifications (Qin et al. 2013). Briefly, a flock of laying Yangzhou geese, about 2000, were placed in 5 connected pens. Each pen was equipped with 5 nest boxes which were equipped with a monitoring system connected to a computer. Video monitoring of laying behaviour and the presence of an egg in the nest box helped determine the timing of oviposition.

\section{Tissue collection}

The theca and granulosa layers were isolated according to the procedure as described previously (Porter et al. 1989, Sechman et al. 2014) with minor modifications. Briefly, the ovaries were collected within 5 min after slaughtering the birds and placed in ice-cold D-PBS. The white and yellowish follicles, and the first largest to the fifth largest hierarchical follicles (F1-F5), were isolated from each ovary using ophthalmic scissors. The white and yellowish follicles were snap-frozen in liquid nitrogen for further analysis. The outer connective tissue surrounding the surface of each F1-F5 follicle was removed. The yolk was then drained through incisions made in the follicular wall. The follicle was inverted and the granulosa layer was teased loose. Then, the granulosa layer and the remaining theca layer tissues were collected separately and snap-frozen in liquid nitrogen. The theca and granulosa layers of hierarchical follicles that became an irregular ellipse or circle in shape and deep yellow in appearance after LPS treatment for 24 or $36 \mathrm{~h}$ (Fig. 3) were not isolated, since the yolks were gelatinous and could not be drained out, which resulted in failure to invert the follicles. Thus, these denatured hierarchical follicles (DF) were directly snap-frozen in liquid nitrogen.

\section{Hormone assays}

Plasma E2 and P4 concentrations were measured by paramagnetic particle and chemiluminescent immunoassay 
Table 1 Primer pairs used for RT-PCR and real-time PCR.

\begin{tabular}{|c|c|c|c|c|}
\hline Target gene & Primer sequence $\left(5^{\prime} \rightarrow 3^{\prime}\right)$ & Accession number & Product size & Annealing temperature \\
\hline \multirow[t]{2}{*}{$\beta$-Actin } & TGACGCAGATCATGTTTGAGA & M26111 & 159 & $57 / 60$ \\
\hline & GCAGAGCGTAGCCСТCATAG & & & \\
\hline \multirow[t]{2}{*}{$T L R 1 \mathrm{~A}$} & CTAACTGATGTTCCAAAA & XM_013185964.1 & 271 & 57 \\
\hline & CATTAAAGTCAAGCTCTG & & & \\
\hline \multirow[t]{2}{*}{$T L R 1 \mathrm{~B}$} & GGCACCAGGCTACAAAATCTG & XM_013185965.1 & 323 & 57 \\
\hline & AAGGGAGTGTCAAGCGAAGG & & & \\
\hline \multirow[t]{2}{*}{$T L R 2 \mathrm{~A}$} & GAAGTGGACTAGGTTCCGTTG & JN982474 & 261 & 60 \\
\hline & GCAATGAAGCCCAAGCAC & & & \\
\hline \multirow[t]{2}{*}{$T L R 2 \mathrm{~B}$} & ATAAGCATAAGAAGGGTAGA & JQ687404 & 196 & 60 \\
\hline & CAATCCCAGGCACAGTAGC & & & \\
\hline \multirow[t]{2}{*}{$T L R 3$} & TAATCTGGCTATTTCTCCT & KC292270 & 160 & 57 \\
\hline & CCAAAGTCGTGCTAAATTA & & & \\
\hline \multirow[t]{2}{*}{ TLR4 } & GGTGCCACATCCATACAAT & HQ436371 & 173 & 60 \\
\hline & TAGGTCAGTCAGAGAGGATA & & & \\
\hline \multirow[t]{2}{*}{ TLR5 } & GGGGAAGAACATATCAACA & KC845942 & 139 & 60 \\
\hline & GATCACTAAAGTACCTGCT & & & \\
\hline \multirow[t]{2}{*}{ TLR7 } & CAАССТTTCCСАGAGСАTT & JQ910168 & 191 & 60 \\
\hline & TCСТCAGCСТAACATACCG & & & \\
\hline \multirow[t]{2}{*}{ TLR15 } & ATATGAGGCTCAGACGAAG & JQ014619 & 100 & 60 \\
\hline & GGTAGTCCACAGCGGTTAG & & & \\
\hline \multirow[t]{2}{*}{ TLR21 } & TGTGCTTCTACСТСТTCACCG & JN573269 & 106 & 60 \\
\hline & TGGTACTTCAGCCGCCAGT & & & \\
\hline
\end{tabular}

(Access Estradiol Assay and Access Progesterone Assay, respectively, Beckman Coulter, Inc.) using the Access Immunoassay Systems (Unicel Dxl 800 Access, Beckman Coulter, Inc.) according to the manufacturer's recommendations. The sensitivity of the $\mathrm{E} 2$ and $\mathrm{P} 4$ assays was $20 \mathrm{pg} / \mathrm{mL}$ and $0.10 \mathrm{ng} / \mathrm{mL}$ respectively. The total imprecision of E2 assay was $\leq 12 \%$ at concentrations $\geq 120 \mathrm{pg} / \mathrm{mL}$. For P4 assay, the imprecision of within run and between run was $\leq 12 \%$ and $\leq 10 \%$ respectively.

\section{RNA isolation, RT-PCR and real-time PCR}

Total RNA was isolated from the white and yellowish follicles, granulosa and theca layers of F1-F5, and DF using the RNAprep Pure Tissue Kit (Tiangen, Beijing, China) according to the manufacturer's protocol. All RNA samples were treated with DNase I digestion to avoid genomic DNA contamination.

For the geese in the control group and after LPS treatment for 24 and $36 \mathrm{~h}$, all RNA samples were reverse transcribed individually using PrimeScript RT Master Mix (TaKaRa). For the other geese, RNA samples of the granulosa layer or theca layer from each goose were mixed with equal concentrations, respectively, and were reverse transcribed. The cDNA samples were stored at $-20^{\circ} \mathrm{C}$ until use.

RT-PCR was performed to examine the expression of TLRs mRNAs in the spleen, white and yellowish follicles, and theca and granulosa layers. The resulting PCR products were sequenced to confirm the correspondence sequences in GenBank.

RT-PCR and real-time PCR assessment was performed using 40 cycles $\left(95^{\circ} \mathrm{C}\right.$ for $15 \mathrm{~s}, 57 / 60^{\circ} \mathrm{C}$ for $30 \mathrm{~s}$ and $72^{\circ} \mathrm{C}$ for 30s). The specific primers (Table 1) used for TLRs were designed using Primer Premier 5 software (PREMIER Biosoft International). For real-time PCR, each sample was assayed in triplicate with $0.6 \mu \mathrm{L}(10 \mathrm{mM})$ of each primer, $1 \mu \mathrm{L}$ of cDNA and $10 \mu \mathrm{L}$ FastStart Universal SYBR Green Master (ROX; Roche Diagnostics) in a total reaction volume of $20 \mu \mathrm{L}$. The data for real-time PCR were analysed by the $2^{-\Delta \Delta C T}$ method to calculate the relative level of $\mathrm{mRNA}$ in each sample using $\beta$-actin as the housekeeping gene.

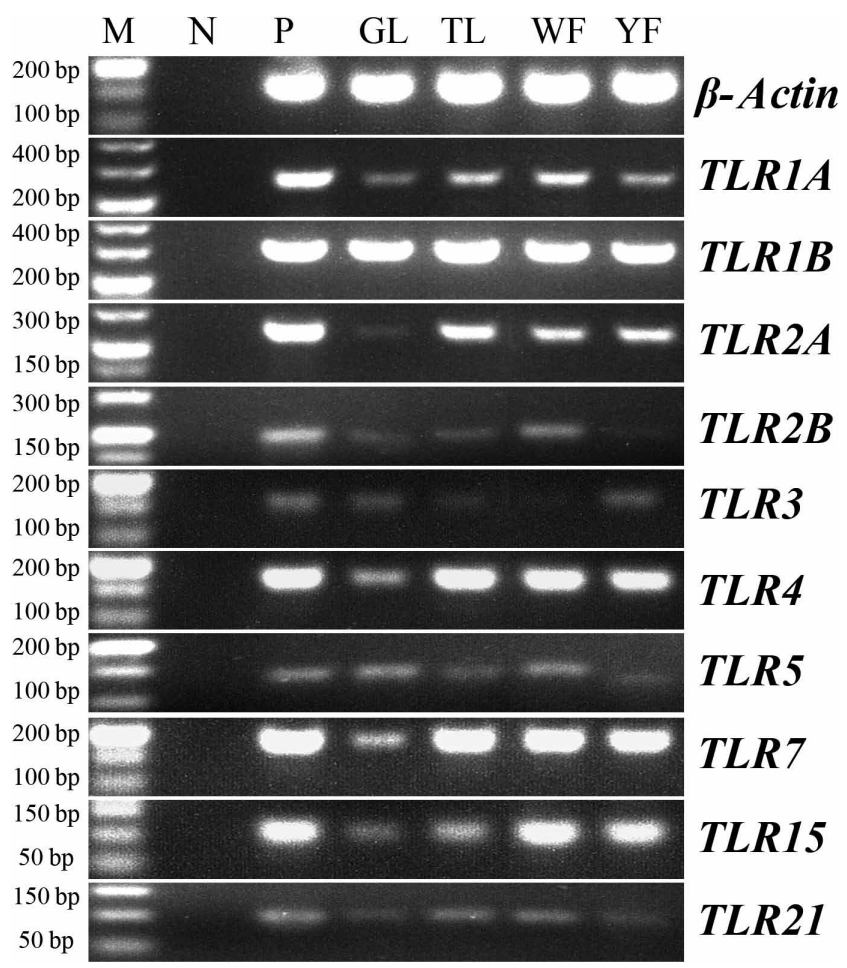

Figure 1 Transcriptional profiling of TLRs in goose ovary. (M) Marker; $(\mathrm{N})$ negative control; $(\mathrm{P})$ positive control (Spleen); (GL) granulosa layer; (TL) theca layer; (WF) white follicle; (YF) yellowish follicle. 

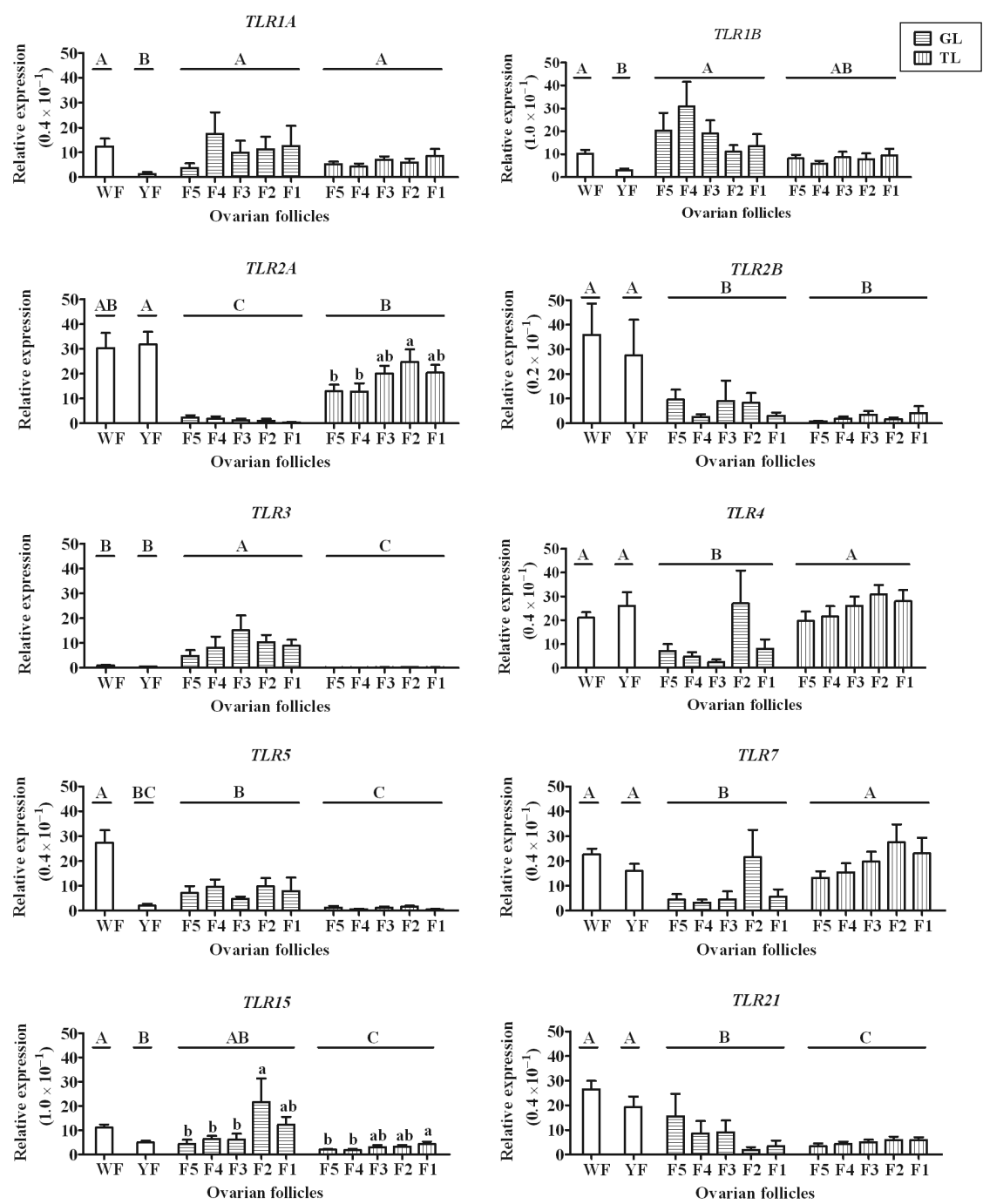

Figure 2 The mRNA expression levels of TLRs in follicles and during follicular growth. (WF) White follicle; (YF) yellowish follicle; (GL) granulosa layer; (TL) theca layer; (F1) the first largest follicle; (F2) the second largest follicle; (F3) the third largest follicle; (F4) the fourth largest follicle; (F5) the fifth largest follicle. Values with the different lower case letters in $\mathrm{GL}$ and/or TL at the same gene are significantly different $(P<0.05)$.

\section{Statistical analysis}

Statistical analyses were carried out using the SPSS statistical software program (version 13.0; SPSS). The data were analysed for normality using the Kolmogorov-Smirnov goodness-of-fit test. They were transformed to logarithms if not normally distributed, and re-tested for normality before analysis. If still not normalised, the data were tested using the equivalent nonparametric test. The results are expressed as the mean \pm S.E.M., and the differences were regarded as significant at $P<0.05$.

To analyse the differential expression among the different follicular tissues, the linear mixed model was carried out with comparisons using the Bonferroni correction. The model included the fixed effect of follicular tissue and random effects of goose and different follicular hierarchy. For the expression levels of TLRs in the hierarchical follicles during follicular growth and LPS-treated follicles at different time points, and plasma E2 and P4 concentrations, one-way ANOVA along with Duncan's multiple range test was applied. The expression levels between the theca or granulosa layer in control group and DF, and between theca or granulosa layer at $24 \mathrm{~h}$ after LPS treatment and DF were analysed using independent- samples $t$-test. The Mann-Whitney $U$-test or Kruskal-Wallis $H$-test was used when transformed data were not normally distributed.

\section{Results}

\section{Transcriptional profiling of TLRs in the goose ovary}

Expression of TLRs in the goose ovarian follicles determined by RT-PCR is presented in Fig. 1. All 10 reported TLRs in hen, namely $T L R \mathrm{~s} 1 A, 1 B, 2 A, 2 B, 3$, $4,5,7,15$ and 21 , were expressed in the white and yellowish follicles, and granulosa and theca layers of hierarchical follicles.

\section{Expression of TLRs during follicular growth}

The expression levels of TLRs in the follicles and during follicular growth are presented in Fig. 2. All 10 members of the TLRs were differentially expressed among the white and yellowish follicles, and granulosa and theca 


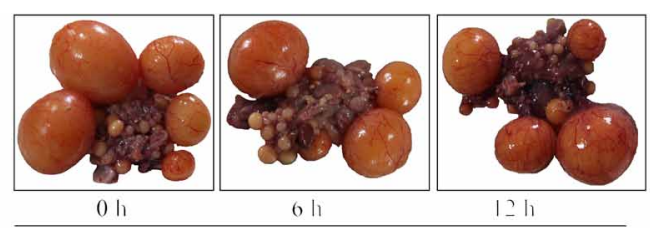

Ilours alter I PS injection

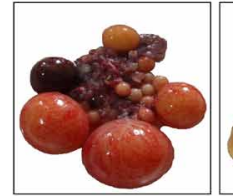

2411

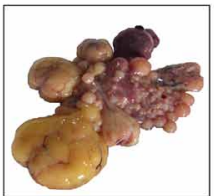

$24 \mathrm{~h}$

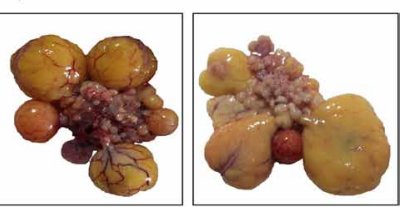

$.36 \mathrm{~h}$

$36 \mathrm{~h}$
Iloursalier I. PS injection

Figure 3 The changes in the morphology of ovary follicles after 0,6 , 12, 24 and $36 \mathrm{~h}$ challenge with LPS.

layers of hierarchical follicles. For the prehierarchical follicles, the expression levels of TLRs $1 A, 1 B, 5$ and 15 were higher $(P<0.05)$ in the white follicles than in the yellowish follicles. Regarding the hierarchical follicles, the expression levels of TLRs 3, 5, 15 and 21 were higher $(P<0.05)$ in the granulosa layer than in the theca layer, while those of TLRs $2 A, 4$ and 7 were lower $(P<0.05)$.

The mRNA levels of TLRs $2 A$ and 15 in the theca layer and TLR15 in the granulosa layer exhibited a tendency to increase with follicular growth. The TLR2A mRNA expression in the $\mathrm{F} 2$ and TLR $15 \mathrm{mRNA}$ expression in the F1 were higher than those of F4 and F5 $(P<0.05)$, while the TLR15 mRNA expression in the F2 was higher than that in the F3, F4 and F5 $(P<0.05)$.

\section{Time course effect of LPS on follicle morphology}

The time course effect of LPS treatment on follicle morphology is shown in Fig. 3. The morphology and appearance colouration of ovarian follicles did not change at 0,6 and $12 \mathrm{~h}$ after LPS treatment. However, at $24 \mathrm{~h}$, the hierarchical follicles of three geese became an irregular ellipse or circle in shape and deep yellow in colour. Moreover, the yolks were gelatinous. The similar morphological changes were found in all five experimental geese at $36 \mathrm{~h}$ after LPS injection.
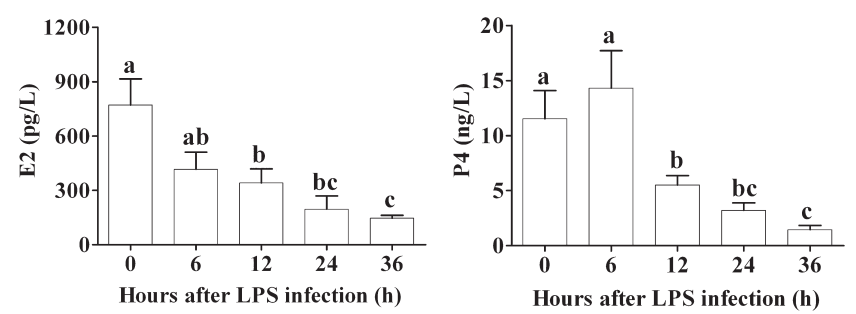

Figure 4 Time course effect of LPS on plasma P4 and E2 concentrations. Values with the different capitals are significantly different $(P<0.05)$.

\section{Time course effect of LPS on plasma P4 and E2 concentrations}

The time course effect of LPS treatment on plasma P4 and E2 concentrations is shown in Fig. 4. Plasma P4 and E2 concentrations were decreased at $12 \mathrm{~h}(P<0.05)$, and then gradually decreased until $36 \mathrm{~h}$ after LPS treatment $(P<0.05)$.

\section{Time course effect of LPS on TLRs mRNA expression in the follicles}

Quantification of the mRNA levels of the expressed TLRS were performed in the prehierarchical and hierarchical follicles after $0,6,12,24$ or $36 \mathrm{~h}$ stimulation with LPS by real-time PCR analysis (Fig. 5). The theca and granulosa layers in DF were not isolated, and hence the time course of mRNA expression in TLRs was not analysed in the theca and granulosa layers at $36 \mathrm{~h}$ after LPS stimulation.

\section{Prehierarchical follicles}

Compared with the control (LPS treatment for $0 \mathrm{~h}$ ), the expression levels of six TLRs were upregulated following LPS stimulation in the white follicles. TLR15 mRNA expression was increased during the $6-24 \mathrm{~h}$ period before declining at $36 \mathrm{~h}(P<0.05)$. The expression levels of both TLRs $2 A$ and 4 were increased $(P<0.05)$ at 12 and $24 \mathrm{~h}$, while TLR5, TLR7 and TLR3 mRNA expression was increased $(P<0.05)$ only at 6,12 and $24 \mathrm{~h}$ respectively. However TLR21 and TLR1A mRNA expression was decreased at $36 \mathrm{~h}$, and during the $24-36 \mathrm{~h}$ period $(P<0.05)$ respectively. There was no significant effect of LPS on TLRs $1 B$ and $2 B$ mRNA expression at all time points.

Regarding the yellowish follicles, stimulation with LPS (1.5 ng/kg BW) resulted in a significant upregulation of eight TLR genes, but all of them were not stimulated at $36 \mathrm{~h}$. The expression levels of TLRs $1 B$ and 15 increased during the $6-24 \mathrm{~h}$ period $(P<0.05)$. TLR1A showed higher expression at 6 and $12 \mathrm{~h} \quad(P<0.05)$. The mRNA levels of TLRs $2 A, 4$ and 5 mRNA were all increased at 12 and $24 \mathrm{~h}(P<0.05)$, while $T L R 2 B$ and $T L R 7$ mRNA expression was increased at $6 \mathrm{~h}$ and at $12 \mathrm{~h}$ $(P<0.05)$ respectively. However LPS stimulation did not significantly influence the expression levels of TLRs 3 and 21.

\section{Hierarchical follicles}

The expression levels of eight TLRs were stimulated, while only TLR3 mRNA expression was decreased at $24 \mathrm{~h}$ after LPS stimulation in the granulosa layer $(P<0.05)$. The expression levels of TLRs 7 and 15 were increased during $6-24 \mathrm{~h}$ period $(P<0.05)$. TLR21, and TLRs $2 A$ and 4 showed higher expression during the $6-12 \mathrm{~h}$ period and during the $12-24 \mathrm{~h}$ period $(P<0.05)$ respectively, while TLR1A, TLR1B and TLR5 

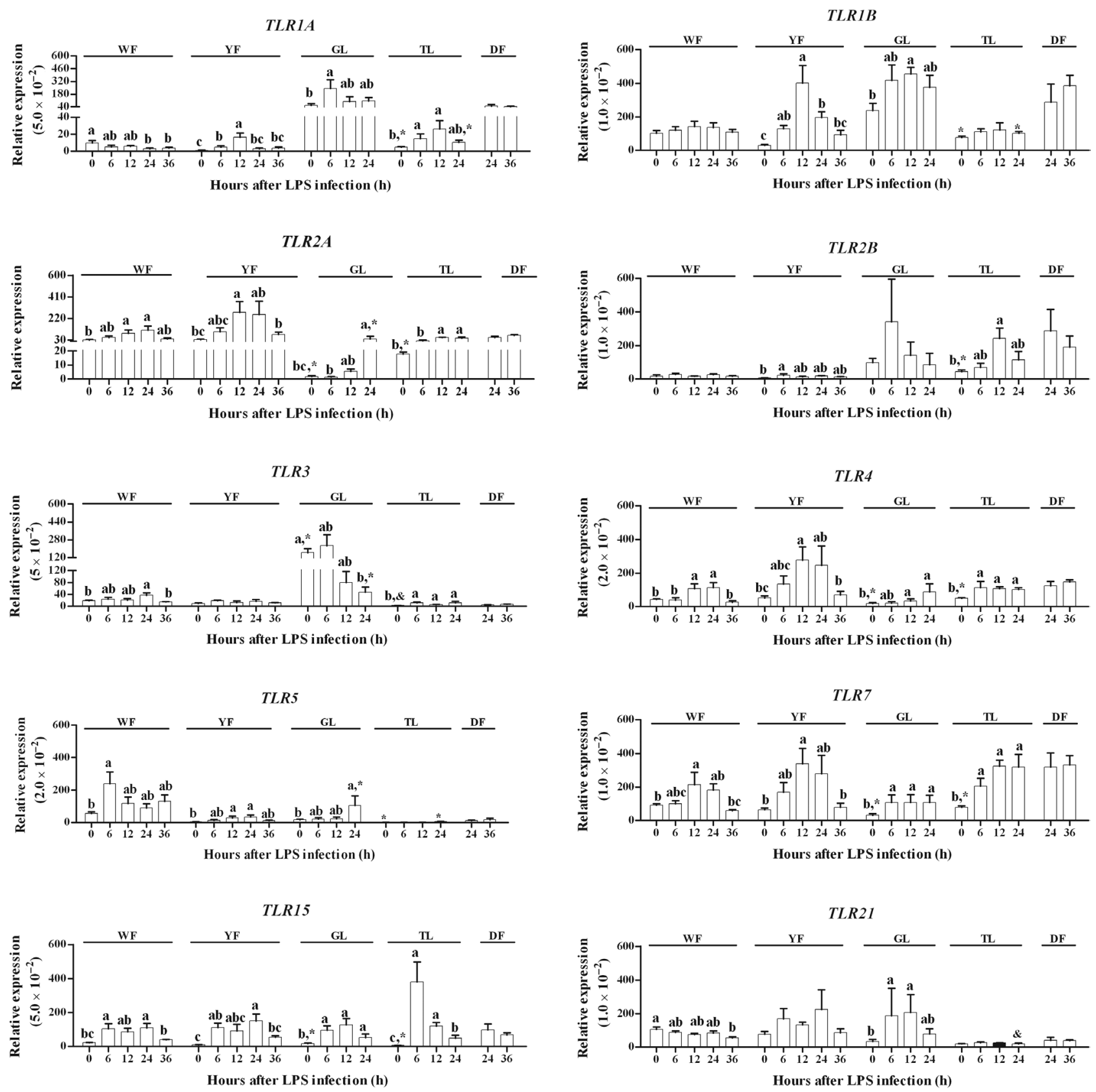

Figure 5 Time course effect of LPS on TLRs mRNA expression in follicles. (WF) White follicle; (YF) yellowish follicle; (GL) granulosa layer; (TL) theca layer. Values with the different lower case letters among different time periods of LPS at the same gene and the same tissue are significantly different $(P<0.05)$.

mRNA expression was increased only at 6,12 and $24 \mathrm{~h}$ $(P<0.05)$ respectively.

In the theca layer, out of ten expressed genes, seven TLRs were stimulated by LPS treatment. The expression levels of TLRs 3, 4, 7 and 15 were all increased during the $6-24 \mathrm{~h}$ period $(P<0.05)$. TLR1A and TLR2A mRNA expression was increased during the $6-12 \mathrm{~h}$ period and during the $12-24 \mathrm{~h}$ period $(P<0.05)$ respectively, while $T L R 2 B$ mRNA expression was increased only at $12 \mathrm{~h}(P<0.05)$.

\section{Differential expression of TLRs between DF and hierarchical follicles}

Differential expression of TLRs between DF and hierarchical follicles is presented in Fig. 5. The expression levels of four TLRs, namely TLRs $2 A, 4,7$ and 15, were higher in the DF than in the granulosa layer, while only the TLR3 mRNA expression was lower. The remaining five TLRs showed similar expression. Except for TLR21, 
the others showed higher expression levels in the DF than in the theca layer $(P<0.05)$.

The TLR1A expression level was higher in the DF than in the granulosa layer at $24 \mathrm{~h}$ after LPS stimulation, while TLRs 3 and 5 expression levels were lower in the DF. The expression levels of four $T L R \mathrm{~s}$, namely $T L R \mathrm{~s} 1 A, 1 B$, 5 and 21 , were higher in the DF than in the theca layer after LPS treatment for $24 \mathrm{~h}$, while the remaining TLRs showed similar expression levels.

\section{Discussion}

To our knowledge, this study firstly elaborated the dynamic changes in the TLRs expression levels and steroidogenesis in avian ovarian follicles during LPS infection. Surprisingly, the 10 types of TLRs, reported in hen so far, were all expressed in white and yellowish follicles, and granulosa and theca layers in goose ovarian follicles. Moreover, except TLRs 2 and 4, the expression levels of all other TLRs increased after LPS treatment. Additionally, it was found that the ovarian follicle morphology was altered after long-time LPS stimulation along with stimulated TLRs expression, which was negatively associated with plasma P4 and E2 concentrations.

TLRs can recognise a broad spectrum of pathogens. For example, TLRs 2A, 3, 4, 5 and 7 recognise the peptidoglycans of gram-positive bacteria, doublestranded RNA, lipopolysaccharides of gram-negative bacteria, bacterial flagellin and single-stranded RNA respectively (Honstettre et al. 2004, Brownlie \& Allan 2011). TLR15 may recognise the bacterial protease and heat stable substance (Nerren et al. 2010, Boyd et al. 2012), and TLR21 may recognise CpG DNA of bacteria (Keestra et al. 2010). Inconsistent with previous study in chicken elucidating that TLRs 2, 4, 5 and 7 express in the theca layer and TLRs 4 and 5 express in the granulosa layer (Subedi et al. 2007), the results of this study show that all 10 TLRs were expressed in the white and yellowish follicles, and granulosa and theca layers of the hierarchical follicles, which further confirm that TLR expression in one species may not be predictive of what will occur in another species (Akira et al. 2001, Yoshimura 2015). Due to the particular mating behaviours in water, it would be challenging for the ovary to recognise the unexpected pathogenic microorganisms ascending from the oviduct (Jiang et al. 2011, Yang et al. 2012). Thus, we suggest that the ovary could effectively recognise invading microorganisms, even if the behavioural habits increase the risk of bacterial infection. Moreover, there are different sensitive sites for pathogens-associated molecular patterns (PAMPs) among different follicular tissues resulting from differential expression of TLRs.

The data of this study show that TLRs $2 A$ and 15 mRNA expression in the theca layer and TLR15 mRNA expression in the granulosa layer increased with follicular growth, which is inconsistent with previous study that the expression levels of TLRs 4 and 5 in the theca layer and that of TLR5 in the granulosa layer increased with the follicular growth (Subedi et al. 2007). This is possibly due to changes in the pathogen involved (Michailidis et al. 2014).

In accordance with the previous studies in chicken reproductive tissues (Ozoe et al. 2009, Woods et al. 2009, Das et al. 2011, Zhang et al. 2012, Ariyadi et al. 2014), the expression levels of TLRs 2 and 4 was upregulated by LPS stimulation in the goose follicles. Moreover, this study, for the first time, showed that LPS stimulated the expression of other TLRs. It has been established that LPS is recognised by TLR4; however whether the LPS is also recognised by TLR2 or not remains ambiguous. Some reports show that TLR2 mediates LPS-induced cellular signalling (Fukui et al. 2001, Heumann \& Roger 2002, Spiller et al. 2007), but the others suggest that LPS activates cellular signalling through TLR4, not TLR2 (Hirschfeld et al. 2000, Tapping et al. 2000). Although the reason for increase in other TLRs mRNA expression after LPS treatment is not known, a recent study reported that TLRS 4 and 5 synergistically initiate the innate immune responses to $E$. coli infection in mouse epididymal epithelial cells (Cheng et al. 2016), indicating a potential interaction among TLRs. The interaction of TLRs and their PAMPs induces an inflammatory response, which involves the host immune (Michailidis et al. 2014). Thus, we suggest that not only exogenous LPS could be directly recognised by $T L R 4$ to initiate an innate immune response, but it could trigger the expression of other TLRs to strengthen this process.

The mature granulosa cells have a more significant and progressively stronger immune response after LPS/ SE infection (Woods et al. 2009, Wang et al. 2014). In this study, after LPS treatment for $6 \mathrm{~h}$, the expression levels of two TLR genes in white follicles, two genes in yellowish follicles, four genes in granulosa layer and five genes in theca layer increased. Furthermore, the longest time duration of stimulated TLRs expression occurs in the theca layer, followed by that in the granulosa layer, yellowish follicles and white follicles, which indicates that the hierarchical follicles have a more significant and progressively stronger immune response than prehierarchical follicles.

Previous studies showed that only TLR3 mRNA expression in the ovary and testis exhibited a tendency to decrease following SE infection (Michailidis et al. 2010, Anastasiadou et al. 2011), but it was not affected in the vagina and chicken Sertoli cells (Michailidis et al. 2011, 2014). In our study, only TLRs $1 A$ and 21 in the white follicles and TLR3 in the granulosa layer exhibited a tendency of decrease in the expression level with prolonged LPS treatment. It is not surprising that the bacterial LPS infection did not stimulate TLRs $1 A, 3$ and 21 expressions because of their specific PAMPs (Schwarz et al. 2007, Chen et al. 2013); however these genes expression pattern in the other ovarian tissues 
were stimulated by LPS in our study. We suggest that the effect of bacterial LPS on TLRs 1, 3 and 21 expression is dependent on the avian reproductive tissue or cell types; however, this molecular mechanism needs to be further studied.

In mammals, LPS enhances apoptosis of corpus luteum and reduces the levels of oestradiol and progesterone in ovary (Price et al. 2013, Magata et al. 2014a,b, Luttgenau et al. 2016b), which may lead to compromised reproductive performance. Similarly, it is reported that the chicken granulosa cells induce suppression of cell proliferation (Tsai et al. 2010) and P4 synthesis (Wang et al. 2014) during SE infection. In this study, preovulatory follicle, especially the larger follicle, morphology is altered after prolonged LPS stimulation, indicating the induction of follicular atresia. Although the preovulatory follicles are generally resistant to become atretic (Johnson 2003, 2015), increased blood flow with follicular growth (Scanes et al. 1982) may result in an accumulation of large amounts of circulating LPS to larger rather than smaller follicles. Furthermore, the circulating E2 and P4 levels are gradually decreased (Fig. 4), which indicates that steroidogenesis of follicle is perturbed. To our knowledge, this is the first study developing an in vivo model to investigate the time course effect of lipopolysaccharide on TLRs expression and steroidogenesis of ovary in birds.

The undifferentiated granulosa cells were more sensitive to LPS/SE-induced apoptosis than differentiated granulosa cells in the chicken, which reflects the susceptibility of granulosa cells at the early stages of maturation to undergo apoptosis in response to select pathogenic stimuli (Woods et al. 2009, Wang et al. 2014). In our study, although the most types of TLRs expression levels in the white and yellowish follicles were stimulated by LPS treatment, expectedly, they were not continuously stimulated until $36 \mathrm{~h}$. We suggest that long-time exogenic LPS stimulation increased prehierarchical granulosa cell apoptosis, and then decreased the TLRs signalling function. Moreover, the growth and maturation of the ovarian follicles is associated with the differentiation of granulosa cells, which occurs before the selection of yellowish follicle into the preovulatory hierarchy (Johnson \& Woods 2009, Johnson 2015). Thus, bacterial infection might inhibit the development of prehierarchical follicles into the hierarchical follicles.

It was surprising that the expression of four genes in $G L$ and nine genes in TL was significantly lower than those in the DF in this study, which indicates that these damaged follicles have more capacity to recognise PAMPs and induce TLR signalling. Furthermore, the circulating E2 and P4 levels gradually decreased at $12 \mathrm{~h}$ after LPS treatment. The avian reproductive tract has the ability to express proinflammatory cytokines and chemokines, which are essential for the activation, differentiation and control of the immune system
(Abdelsalam et al. 2011, Nii et al. 2011, Zhang et al. 2012, Sonoda et al. 2013, Michailidis et al. 2014). Moreover, the LPS stimulation resulted in the increased influx of heterophil-like cells and T cells in the theca layers of follicles (Abdelsalam et al. 2011). It is likely that the innate immune capabilities in the ovarian follicular cells modulate their endocrine function (Herath et al. 2007). Thus, together with the results of plasma P4 and E2 concentrations and follicle morphology, we propose that the immune function of the avian ovarian follicles gradually grows for responding to pathogen infection, while steroidogenesis gradually declines during LPS infection. However this continuous inflammatory reaction might damage the follicular structure.

It has been reported that through TLRs 2 and 4, LPS reduced steroidogenesis in mammalian ovaries (Bromfield \& Sheldon 2011, Price \& Sheldon 2013, Price et al. 2013, Glynn et al. 2014, Luttgenau et al. 2016a). Likewise, LPS stimulated the expression levels of TLRs 2 and 4, accompanied by lowered steroidogenesis in birds (Woods et al. 2009, Wang et al. 2014). The results presented in this study showed that the expression pattern of TLRs $2 A$ and 4 genes was similar to the other genes, such as TLR15 in the white follicles; TLRs $1 B, 5$ and 15 in the yellowish follicles; TLRs 7 and 15 in the granulosa layer and $T L R s \quad 1 A, 2 B, 3,7$ and 15 in the theca layer, which were negatively correlated with the kinetics of plasma P4 and E2 concentrations during LPS infection. In the avian nonhierarchical follicles, E2 synthesis is higher than that in the hierarchical follicles, whereas P4 synthesis remains opposite (Sechman et al. 2014). Meanwhile, the granulose layer produces mainly P4, while the theca layer produces E2 Johnson et al. 2002, Woods \& Johnson 2005, Johnson \& Woods 2009, Johnson 2015). Thus, we suggested that not only TLRs 2 and 4, but also TLRs $1 A, 1 B, 3,5,7$, and 15 may play important roles in LPS-inhibited steroidogenesis after interacting with their ligands in birds. Moreover, these effects are dependent on the stage of follicular maturation and type of follicular cells.

In conclusion, the ten TLRs are expressed in the Chinese goose ovarian follicles, and LPS infection triggers innate immune response not only through TLR4, but also by stimulating the expression of the other TLRs. Moreover, LPS alters the follicular structure and reduces the steroidogenesis, which might explain the phenomenon that increased microorganism concentrations are associated with decreased laying performance in goose. The data presented in this study also suggest that LPS may inhibit the steroidogenesis through induced TLRs expression in the ovarian follicles. In addition, these effects may be dependent on the stage of follicle maturation and the type of follicular cells. Our data expand previous understanding and provide novel insight into the function of TLRs in the avian ovary follicles. 


\section{Declaration of interest}

The authors declare that there is no conflict of interest that could be perceived as prejudicing the impartiality of the research reported.

\section{Funding}

This work was supported by the Jiangsu Natural Science Fund (grant number BK20130718), Jiangsu Agriculture Science and Technology Innovation Fund (grant number CX(13)5041 and CX(15)1008), and China Agriculture Research System (grant number CARS-43-16).

\section{Acknowledgements}

The authors wish to thank Prof. AiDong Sun and MingJun Shen for their help in the collection of the experimental materials.

\section{References}

Abdelsalam M, Isobe N \& Yoshimura Y 2011 Effects of lipopolysaccharide on the expression of proinflammatory cytokines and chemokines and influx of leukocytes in the hen ovary. Poultry Science 90 2054-2062. (doi:10.3382/ps.2011-01394)

Aderem A \& Ulevitch RJ 2000 Toll-like receptors in the induction of the innate immune response. Nature $\mathbf{4 0 6}$ 782-787. (doi:10.1038/35021228)

Akira S, Takeda K \& Kaisho T 2001 Toll-like receptors: critical proteins linking innate and acquired immunity. Nature Immunology 2 675-680. (doi:10.1038/90609)

Anastasiadou M, Theodoridis A, Avdi M \& Michailidis G 2011 Changes in the expression of Toll-like receptors in the chicken testis during sexual maturation and Salmonella infection. Animal Reproduction Science 128 93-99. (doi:10.1016/j.anireprosci.2011.09.003)

Ariyadi B, Isobe N \& Yoshimura Y 2014 Toll-like receptor signaling for the induction of mucin expression by lipopolysaccharide in the hen vagina. Poultry Science 93 673-679. (doi:10.3382/ps.2013-03667)

Boyd AC, Peroval MY, Hammond JA, Prickett MD, Young JR \& Smith AL 2012 TLR15 is unique to avian and reptilian lineages and recognizes a yeast-derived agonist. Journal of Immunology 189 4930-4938. (doi:10.4049/jimmunol.1101790)

Bromfield JJ \& Sheldon IM 2011 Lipopolysaccharide initiates inflammation in bovine granulosa cells via the TLR4 pathway and perturbs oocyte meiotic progression in vitro. Endocrinology 152 5029-5040. (doi:10.1210/en.2011-1124)

Bromfield JJ \& Sheldon IM 2013 Lipopolysaccharide reduces the primordial follicle pool in the bovine ovarian cortex ex vivo and in the murine ovary in vivo. Biology of Reproduction 88 98. (doi:10.1095/ biolreprod.112.106914)

Brownlie R \& Allan B 2011 Avian toll-like receptors. Cell and Tissue Research 343 121-130. (doi:10.1007/s00441-010-1026-0)

Chen S, Cheng A \& Wang M 2013 Innate sensing of viruses by pattern recognition receptors in birds. Veterinary Research 4482. (doi:10.1186/1297-9716-44-82)

Cheng L, Chen Q, Zhu W, Wu H, Wang Q, Shi L, Zhao X \& Han D 2016 Toll-like receptors 4 and 5 cooperatively initiate the innate immune responses to uropathogenic Escherichia coli infection in mouse epididymal epithelial cells. Biology of Reproduction 94 58. (doi:10.1095/ biolreprod.115.136580)

Cronin JG, Turner ML, Goetze L, Bryant CE \& Sheldon IM 2012 Toll-like receptor 4 and MYD88-dependent signaling mechanisms of the innate immune system are essential for the response to lipopolysaccharide by epithelial and stromal cells of the bovine endometrium. Biology of Reproduction 86 51. (doi:10.1095/biolreprod.111.092718)

Das SC, Isobe N \& Yoshimura Y 2011 Expression of Toll-like receptors and avian beta-defensins and their changes in response to bacterial components in chicken sperm. Poultry Science $90 \quad 417-425$. (doi:10.3382/ps.2010-00850)

Fukui A, Inoue N, Matsumoto M, Nomura M, Yamada K, Matsuda Y, Toyoshima K \& Seya T 2001 Molecular cloning and functional characterization of chicken toll-like receptors. A single chicken toll covers multiple molecular patterns. Journal of Biological Chemistry 276 47143-47149. (doi:10.1074/jbc.M103902200)

Glynn DJ, Hutchinson MR \& Ingman WV 2014 Toll-like receptor 4 regulates lipopolysaccharide-induced inflammation and lactation insufficiency in a mouse model of mastitis. Biology of Reproduction $\mathbf{9 0}$ 91. (doi:10.1095/biolreprod.114.117663)

Herath S, Williams EJ, Lilly ST, Gilbert RO, Dobson H, Bryant CE \& Sheldon IM 2007 Ovarian follicular cells have innate immune capabilities that modulate their endocrine function. Reproduction 134 683-693. (doi:10.1530/REP-07-0229)

Herzog K, Struve K, Kastelic JP, Piechotta M, Ulbrich SE, Pfarrer C, Shirasuna K, Shimizu T, Miyamoto A \& Bollwein H 2012 Escherichia coli lipopolysaccharide administration transiently suppresses luteal structure and function in diestrous cows. Reproduction 144 467-476. (doi:10.1530/REP-12-0138)

Heumann D \& Roger T 2002 Initial responses to endotoxins and Gramnegative bacteria. Clinica Chimica Acta 323 59-72. (doi:10.1016/ S0009-8981(02)00180-8)

Hirschfeld M, Ma Y, Weis JH, Vogel SN \& Weis JJ 2000 Cutting edge: repurification of lipopolysaccharide eliminates signaling through both human and murine toll-like receptor 2. Journal of Immunology $\mathbf{1 6 5}$ 618-622. (doi:10.4049/jimmunol.165.2.618)

Honstettre A, Ghigo E, Moynault A, Capo C, Toman R, Akira S, Takeuchi O, Lepidi H, Raoult D \& Mege JL 2004 Lipopolysaccharide from Coxiella burnetii is involved in bacterial phagocytosis, filamentous actin reorganization, and inflammatory responses through Toll-like receptor 4. Journal of Immunology 172 3695-3703. (doi:10.4049/ jimmunol.172.6.3695)

Jiang DL, Liu L, Wang CL, Chen F, Sun AD \& Shi ZD 2011 Raising on water stocking density reduces geese reproductive performances via water bacteria and lipopolysaccharide contaminations in 'Geese-Fish' production system. Journal of Integrative Agriculture 10 1459-1466. (doi:10.1016/s1671-2927(11)60139-9)

Johnson AL 2003 Intracellular mechanisms regulating cell survival in ovarian follicles. Animal Reproduction Science 78 185-201. (doi:10.1016/S0378-4320(03)00090-3)

Johnson PA 2012 Follicle selection in the avian ovary. Reproduction in Domestic Animals 47 (Supplement 4) 283-287. (doi:10.1111/j.14390531.2012.02087.x)

Johnson AL 2015 Ovarian follicle selection and granulosa cell differentiation. Poultry Science $\mathbf{9 4}$ 781-785. (doi:10.3382/ps/peu008)

Johnson AL \& Woods DC 2009 Dynamics of avian ovarian follicle development: cellular mechanisms of granulosa cell differentiation. General and Comparative Endocrinology 163 12-17. (doi:10.1016/j. ygcen.2008.11.012)

Johnson AL, Solovieva EV \& Bridgham JT 2002 Relationship between steroidogenic acute regulatory protein expression and progesterone production in hen granulosa cells during follicle development. Biology of Reproduction 67 1313-1320. (doi:10.1095/biolreprod67.4.1313)

Kannaki TR, Shanmugam M \& Verma PC 2011 Toll-like receptors and their role in animal reproduction. Animal Reproduction Science 125 1-12. (doi:10.1016/j.anireprosci.2011.03.008)

Keestra AM, de Zoete MR, Bouwman LI \& van Putten JP 2010 Chicken TLR21 is an innate CPG DNA receptor distinct from mammalian TLR9. Journal of Immunology $\mathbf{1 8 5}$ 460-467. (doi:10.4049/ jimmunol.0901921)

Luttgenau J, Herzog K, Struve K, Latter S, Boos A, Bruckmaier RM, Bollwein H \& Kowalewski MP 2016a LPS-mediated effects and spatiotemporal expression of TLR2 and TLR4 in the bovine corpus luteum. Reproduction 151 391-399. (doi:10.1530/REP-15-0520)

Luttgenau J, Moller B, Kradolfer D, Wellnitz O, Bruckmaier RM, Miyamoto A, Ulbrich SE \& Bollwein H 2016b Lipopolysaccharide enhances apoptosis of corpus luteum in isolated perfused bovine ovaries in vitro. Reproduction 151 17-28. (doi:10.1530/REP-15-0281)

Magata F, Horiuchi M, Echizenya R, Miura R, Chiba S, Matsui M, Miyamoto A, Kobayashi Y \& Shimizu T 2014a Lipopolysaccharide in ovarian follicular fluid influences the steroid production in large follicles 
of dairy cows. Animal Reproduction Science 144 6-13. (doi:10.1016/j. anireprosci.2013.11.005)

Magata F, Horiuchi M, Miyamoto A \& Shimizu T 2014b Lipopolysaccharide (LPS) inhibits steroid production in theca cells of bovine follicles in vitro: distinct effect of LPS on theca cell function in pre- and post-selection follicles. Journal of Reproduction and Development 60 280-287. (doi:10.1262/jrd.2013-124)

Michailidis G, Theodoridis A \& Avdi M 2010 Transcriptional profiling of Toll-like receptors in chicken embryos and in the ovary during sexual maturation and in response to Salmonella enteritidis infection. Animal Reproduction Science 122 294-302. (doi:10.1016/j. anireprosci.2010.09.004)

Michailidis G, Theodoridis A \& Avdi M 2011 Effects of sexual maturation and Salmonella infection on the expression of Toll-like receptors in the chicken vagina. Animal Reproduction Science 123 234-241. (doi:10.1016/j.anireprosci.2011.01.010)

Michailidis G, Anastasiadou M, Guibert E \& Froment P 2014 Activation of innate immune system in response to lipopolysaccharide in chicken Sertoli cells. Reproduction 148 259-270. (doi:10.1530/REP-14-0064)

Nerren JR, He H, Genovese K \& Kogut MH 2010 Expression of the avianspecific toll-like receptor 15 in chicken heterophils is mediated by gramnegative and gram-positive bacteria, but not TLR agonists. Veterinary Immunology and Immunopathology 136 151-156. (doi:10.1016/j. vetimm.2010.02.017)

Nii T, Sonoda Y, Isobe N \& Yoshimura Y 2011 Effects of lipopolysaccharide on the expression of proinflammatory cytokines and chemokines and the subsequent recruitment of immunocompetent cells in the oviduct of laying and molting hens. Poultry Science 90 2332-2341. (doi:10.3382/ ps.2011-01596)

Oguejiofor CF, Cheng Z, Abudureyimu A, Anstaett OL, Brownlie J, FouladiNashta AA \& Wathes DC 2015 Global transcriptomic profiling of bovine endometrial immune response in vitro. II. Effect of bovine viral diarrhea virus on the endometrial response to lipopolysaccharide. Biology of Reproduction 93 9. (doi:10.1095/biolreprod.114.127761)

Ozoe A, Isobe N \& Yoshimura Y 2009 Expression of Toll-like receptors (TLRs) and TLR4 response to lipopolysaccharide in hen oviduct. Veterinary Immunology and Immunopathology 127 259-268. (doi:10.1016/j. vetimm.2008.10.325)

Porter TE, Hargis BM, Silsby JL \& el Halawani ME 1989 Differential steroid production between theca interna and theca externa cells: a three-cell model for follicular steroidogenesis in avian species. Endocrinology 125 109-116. (doi:10.1210/endo-125-1-109)

Price JC \& Sheldon IM 2013 Granulosa cells from emerged antral follicles of the bovine ovary initiate inflammation in response to bacterial pathogen-associated molecular patterns via Toll-like receptor pathways. Biology of Reproduction 89 119. (doi:10.1095/biolreprod.113.110965)

Price JC, Bromfield JJ \& Sheldon IM 2013 Pathogen-associated molecular patterns initiate inflammation and perturb the endocrine function of bovine granulosa cells from ovarian dominant follicles via TLR2 and TLR4 pathways. Endocrinology 154 3377-3386. (doi:10.1210/en.20131102)

Qin Q, Sun A, Guo R, Lei M, Ying S \& Shi Z 2013 The characteristics of oviposition and hormonal and gene regulation of ovarian follicle development in Magang geese. Reproductive Biology and Endocrinology 11 65. (doi:10.1186/1477-7827-11-65)

Saut JP, Healey GD, Borges AM \& Sheldon IM 2014 Ovarian steroids do not affect bovine endometrial cytokine or chemokine responses to Escherichia coli or LPS in vitro. Reproduction 148 593-606. (doi:10.1530/REP-14-0230)

Scanes CG, Mozelic H, Kavanagh E, Merrill G \& Rabii J 1982 Distribution of blood flow in the ovary of domestic fowl (Gallus domesticus) and changes after prostaglandin F-2 alpha treatment. Journal of Reproduction and Fertility 64 227-231. (doi:10.1530/jrf.0.0640227)

Schwarz H, Schneider K, Ohnemus A, Lavric M, Kothlow S, Bauer S, Kaspers B \& Staeheli P 2007 Chicken toll-like receptor 3 recognizes its cognate ligand when ectopically expressed in human cells. Journal of Interferon and Cytokine Research 27 97-101. (doi:10.1089/ jir.2006.0098)
Sechman A, Antos P, Katarzynska D, Grzegorzewska A, Wojtysiak D \& Hrabia A 2014 Effects of 2,3,7,8-tetrachlorodibenzo-p-dioxin on secretion of steroids and STAR, HSD3B and CYP19A1 mRNA expression in chicken ovarian follicles. Toxicology Letters 225 264-274. (doi:10.1016/j.toxlet.2013.12.021)

Shimada M, Yanai Y, Okazaki T, Noma N, Kawashima I, Mori T \& Richards JS 2008 Hyaluronan fragments generated by sperm-secreted hyaluronidase stimulate cytokine/chemokine production via the TLR2 and TLR4 pathway in cumulus cells of ovulated COCs, which may enhance fertilization. Development 135 2001-2011. (doi:10.1242/ dev.020461)

Sonoda Y, Abdel Mageed AM, Isobe N \& Yoshimura Y 2013 Induction of avian beta-defensins by CpG oligodeoxynucleotides and proinflammatory cytokines in hen vaginal cells in vitro. Reproduction 145 621-631. (doi:10.1530/REP-12-0518)

Spiller S, Dreher S, Meng G, Grabiec A, Thomas W, Hartung T, Pfeffer K, Hochrein H, Brade H, Bessler W et al. 2007 Cellular recognition of trimyristoylated peptide or enterobacterial lipopolysaccharide via both TLR2 and TLR4. Journal of Biological Chemistry 282 13190-13198. (doi:10.1074/jbc.M610340200)

Subedi K, Isobe N, Nishibori M \& Yoshimura Y 2007 Changes in the expression of toll-like receptor mRNAs during follicular growth and in response to lipopolysaccharide in the ovarian follicles of laying hens. Journal of Reproduction and Development 53 1227-1235. (doi:10.1262/ jrd.19076)

Tapping RI, Akashi S, Miyake K, Godowski PJ \& Tobias PS 2000 Tolllike receptor 4, but not toll-like receptor 2, is a signaling receptor for Escherichia and Salmonella lipopolysaccharides. Journal of Immunology 165 5780-5787. (doi:10.4049/jimmunol.165.10.5780)

Temperley ND, Berlin S, Paton IR, Griffin DK \& Burt DW 2008 Evolution of the chicken Toll-like receptor gene family: a story of gene gain and gene loss. BMC Genomics 9 62. (doi:10.1186/1471-2164-9-62)

Tsai HJ, Chiu CH, Wang CL \& Chou CH 2010 A time-course study of gene responses of chicken granulosa cells to Salmonella Enteritidis infection. Veterinary Microbiology 144 325-333. (doi:10.1016/j. vetmic.2010.01.004)

Wang CL, Fan YC, Chun-Hsien T, Chiu CH, Tsai HJ \& Chou CH 2014 Salmonella Enteritidis infection slows steroidogenesis and impedes cell growth in hen granulosa cells. Avian Diseases 58 511-517. (doi:10.1637/10846-041414-Reg.1)

Woods DC \& Johnson AL 2005 Regulation of follicle-stimulating hormone-receptor messenger RNA in hen granulosa cells relative to follicle selection. Biology of Reproduction 72 643-650. (doi:10.1095/ biolreprod.104.033902)

Woods DC, Schorey JS \& Johnson AL 2009 Toll-like receptor signaling in hen ovarian granulosa cells is dependent on stage of follicle maturation. Reproduction 137 987-996. (doi:10.1530/REP-08-0320)

Yang XW, Liu L, Jang DL, Wang CL, Sun AD \& Shi ZD 2012 Improving geese production performance in 'Goose-Fish' production system by competitive reduction of pathogenic bacteria in pond water. Journal of Integrative Agriculture 11 993-1001. (doi:10.1016/S20953119(12)60091-4)

Yoshimura Y 2015 Avian beta-defensins expression for the innate immune system in hen reproductive organs. Poultry Science 94 804-809. (doi:10.3382/ps/peu021)

Zhang M, Nii T, Isobe N \& Yoshimura Y 2012 Expression of Toll-like receptors and effects of lipopolysaccharide on the expression of proinflammatory cytokines and chemokine in the testis and epididymis of roosters. Poultry Science 91 1997-2003. (doi:10.3382/ps.2012-02236)

Received 6 July 2016

First decision 8 August 2016

Revised manuscript received 6 January 2017

Accepted 7 February 2017 